56. VALIDATION OF THE PULSED DOPPLER TECHNIQUE FOR ASSESSMENT OF CEREBRAL BLOOD FLOW VELOCITY. Bo P.W. Lunde11, Daniel P. Lindstrom, Thomas G. Arnold, Kathleen A. Kennedy, Hakan Sunde1l, Vanderbilt Univ. Sch. of Med., Dept. of Ped., Nashville. (1699)

57. REGIONAL CEREBRAL BLOOD FLOW (CBF) IN A RAT MODEL PARALLELS CHANGES IN HUMAN PERINATAL HYPOXICISCHEMIC ENCEPHALOPATHY (HIE). F. Silverstein, K. Hassett, and M. Johnston (Spon. by Gary Goldstein), Univ. of Michigan, Dept. of Ped. Neuro., Ann Arbor. (1686)

58. SYMPATHETIC NERVE STIMULATION ATTENUATE CEREBRAL BLOOD FLOW (CBF) IN HYPERCAPNIC NEWBORN PIGLETS. L. Craig Wagerle, Savitri P. Kumar, and Maria Delivoria-Papadopoulos, Univ of Pennsylvania, Dept. of Physiol. and Ped., Philadelphia. (1726)

59. CERVICAL CORD COMPRESSION IN ACHONDROPLASIA. C. Reid, H. Wang, R. McPherson, B. Maria, C. Francomano, J. Phillips, III, A. Rosenbaum and R. Pyeritz, Johns Hopkins Univ. Sch. of Med., Dept. of Ped., Radiol., Anesth. and Neuro., Baltimore. (1715)

60. SYSTEMIC HYPERTENSION ASSOCIATED WITH POOR OUTCOME AFTER ACUTE BRAIN INJURY. Robert K. Kanter, James B. Carrol1, Ernest M. Post (Spon. by Roger E. Spitzer), SUNY, Upstate Med. Ctr., Dept. of Ped., Syracuse. (1689)

\title{
POSTER SESSION III
}

\author{
Thursday, May 3, 1984, 7:30 AM \\ West Lounge/Garden Lane/Embarcadero
}

1. LEVEL, TREND AND VARIABILITY OF BLOOD PRESSURE DURING CHILDHOOD: THE MUSCATINE STUDY. Ronald M. Lauer, William R. Clarke, Univ. of Iowa, Dept. of Ped. and Prevent. Med., Iowa City. (184)

2. SYSTEMIC AND PULMONARY VASCULAR EFFECTS OF DOBUTAMIN IN NEWBORN LAMBS. Becky Williams, James E. Fewell, and Donald E. Hill, Univ. of Arkansas for Med. Sci., Dept. of Ped., Little Rock. (218)

3. NON-INVASIVE DETECTION OF CARDIAC SPECIALIZED CONDUCTION SYSTEM POTENTIALS IN PEDIATRIC PATIENTS. Ehud Krongrad, M.D., Nan-Koong Wang, M.D., Yoram Lass, M.D., Coll. of Physicians \& Surg., Columbia Univ., New York, and Sackler Sch. of Med., Tel Aviv. (173)

4. LONG-TERM RESULTS OF BALLOON VALVULOPLASTY OF THE PULMONARY VALVE. D. Kveselis, A.P. Rocchini, A. Rosenthal, Univ. of Michigan. (176)

5. DOPAMINE(DA) INFUSION: EFFECTS ON HEMODYNAMIC AND CATECHOLAMINE (CA) CONCENTRATIONS. Arno L. Zaritsky, Murray M. Pollack, Deborah H. Schaible, C. Raymond Lake (Spon. by G. Rosenquist), George Washington Univ. Sch. of Med., Children's Hosp. Nat1. Med. Ctr., Dept. of Ped., Anesth., Washington. (228) 
6. POTENTIAL HYDRAULIC INPUT POWER CHANGES IN THE LEFT PULMONARY ARTERIAL CIRCULATION AT BIRTH. Stephen H. Bennett, Jay M. Milstein, Boyd W. Goetzman, Dept. of Ped., Univ. of California, Davis. (142)

7. CONTINUOUS WAVE DOPPLER AND PDA: THE VELOCITY INDEX. J.L. Bass, G. Lund, J. Berry, J. Rysavy, K. Amplatz, S. Einzig, Univ of Minnesota, Dept. of Ped., Minneapolis. (139)

8. VIRILIZATION IN A 45,X/46, $\mathrm{Xr}(\mathrm{X}) / 46, \mathrm{Xdel}(\mathrm{X})(\mathrm{p} 21: ; \mathrm{q} 11:$ ) FEMALE. S.E. Oberfield, L.S. Levine, S. Pang, J. Wedgwood, W. Sweeney, III, C. Moreira-Filho, S. Wachtel, M.I. New, New York Hosp.-Cornell Med. Ctr., New York. (768)

9. DYSMORPHIC SYNDROME, SPHEROCYTOSIS AND PARTIAL DELETION OF THE SHORT ARM OF CHROMOSOME 8. Robert R. Chilcote, Barbara Jones, Carlton Dampier, Michelle LeBeau, Janet Rowley, Yury Verlinsky, and Eugene Pergament (Spon. by Marc 0. Beem), Univ. of Chicago, Wyler Children's Hosp. and Michael Reese Hosp., Chicago. (748)

10. INBORN ERRORS OF UREAGENESIS; RESULTS OF THERAPY IN 44 PATIENTS. Saul Brusilow, Johns Hopkins Dept. of Ped., Baltimore. (746)

11. L-CARNITINE FOR CYSTIC FIBROSIS. Paul T. Benke, Budge McKay, Jose Foradada, Dept. of Ped., Univ. of Miami Sch. of Med., Miami. (743)

12. PLASMA ANTITHROMBIN III LEVELS IN CHILDREN WITH HOMOZYGOUS SICKLE CELL DISEASE (SCD). Gungor Karayalcin, David Chung, Pretti Pinto and Philip Lanzkowsky, Sch. of Med., Hlth. Sci. Ctr., SUNY at Stony Brook, Children's Hosp. of LIJ-HMC, Dept. of Ped., New Hyde Park. (878)

13. IMPAIRED SPLENIC RETICULOENDOTHELIAL FUNCTION IN CHILDREN WITH CANCER. George R. Buchanan, Christine A. Holtkamp, Dept. of Ped., Univ. of Texas H1th. Sci. Ctr. at Dallas, Southwestern Med. Sch. \& Children's Med. Ctr., Dallas. (845)

14. SPLENECTOMY IN SPHEROCYTOSIS: IS IT WORTH THE RISK? Catherine S. Manno and Alan R. Cohen )Spon. by Elias Schwartz), Univ. of Pennsylvania Sch. of Med. and Children's Hosp. of Philadelphia, Dept. of Ped., Philadelphia. (893)

15. INHIBITION OF TUMOR GROWTH BY DIETARY RESTRICTION OF SODIUM. Burton P. Fine, Thomas N. Denny, Nancy J. Lestrange and Thomas R. Walters (Spon. by 0 . Robert Levine), UMDNJ-New Jersey Med. Sch., Newark. (863)

16. ISOLATED THROMBOCYTOPENIA FOLLOWING ALLOGENEIC BONE MARROW TRANSPLANTATION. L.R. First, B.R. Smith, J.M. Lipton, D.G. Nathan, R.P. Parkman, J.M. Rappeport, Harvard Med. Sch., Dept. of Med. and Ped., Boston. (864)

17. ERYTHROCYTE CREATINE LEVELS (EC) AND THE DIAGNOSIS OF HEMOLYTIC DISEASE IN NEWBORN INFANT (HDN). Alvin Zipursky, Elizabeth J. Brown, Dolores Chachula, Dept. of Ped., Hosp. for Sick Children \& the Univ. of Toronto. (933)

18. NORMAL CHEMOTAXIS AND OTHER GRANULOCYTE FUNCTIONS IN HEMOPHILIACS WITH ABNORMAL T HELPER/T SUPPRESSOR CELL RATIOS. P. Kempert, J. Katz, C. Mallett, C. Van Den Ven, B. Walter, G. Bennetts, M. Cairo (Spon. by Donald Sperling), UCI/CHOC, Orange. (883) 
19. SEQUELAE OF EARLY-ONSET GBS NEONATAL MENINGITIS. Twei Chin, Pamela Fitzhardinge, Univ. of Toronto, Hosp. for Sick Children, Dept. of Ped., Toronto. (1361)

20. POLYSONO GRAPHIC FINDINGS AT DISCHARGE IN INFANTS BORN AT LESS THAN 32 weeks of gestational age (ga). Julio Perez Fontan, Samuel Hawgood, Gregory P. Heldt, William H. Tooley, Cardiovasc. Res. Inst., Univ. of California, San Francisco. (1362)

21. DOCUMENTATION OF PRENATAL BRAIN INJURY. Boyd W. Goetzman, Jeffrey A. Lindenberg, William Ellis, Sch. of Med., Dept. of Ped. and Path., Univ. of California, Davis. (1366)

22. CARDIOPULMONARY EFFECTS OF PROPHYLACTIC INDOMETHACIN IN THE VERY-LOWBIRTH-WEIGHT INFANT. E.S. Setzer, E. Torres-Arraut, M. Gomez-de1-Rio, M.L. Young, I Pacheco, P.L. Ferrer, R.F. Scherf, E. Bancalari, Univ. of Miami, Jackson Mem. Hosp., Dept. of Ped., Miami. (1500)

23. THE PREVENTION OF RESPIRATORY DISTRESS SYNDROME IN PREMATURE INFANTS: EFFICACY OF ANTENATAL AMINOPHYLLINE TREATMENT VERSUS PRENATAL GLUCOCORTICOID ADMINISTRATION. Bruno Granati, Pasquale V. Grella, Andrea Pettenazzo, Laura Di Lenardo, and Firmino F. Rubaltelli (Spon. by Philip D. Walson), Univ. of Padova, Clinica Pediatrica and Clinica Ostetrica, Italy. (1371)

24. CPAP ONLY REDUCES NEONATAL APNEA ASSOCIATED WITH AIRWAY OBSTRUCTION. M.J. Miller, W.A. Carlo, R.J. Martin, Dept. of Ped., Rainbow B. \& C. Hosp., CWRU, Cleveland. (1430)

25. THE EFFECTS OF APNEA AND BRADYCARDIA ON CEREBRAL BLOOD FLOW VELOCITY (CBFV) IN THE PRETERM INFANT. Jeffrey M. Perlman, Joseph J. Volpe, Washington Univ. Sch. of Med., St. Louis Children's Hosp., Dept. of Ped. and Neurol., St. Louis. (1547)

26. THE EFFECT OF HYPERVENTILATION ON TOTAL CALCIUM, IONIZED CALCIUM AND SERUM PHOSPHORUS IN NEONATES. E. M. Bifano, J. Watchko and W.H. Bergstrom, Dept. of Ped., SUNY, Upstate Med. Ctr., Syracuse. (1301)

27. EFFECTIVENESS OF EARLY PHOTOTHERAPY IN VERY-LOW-BIRTH-WEIGHT (VLBW) INFANTS. M.Curtis-Cohen, G.E. Stah1, J. Ennever, W. Speck and R.A. Polin, Dept. of Ped., Children's Hosp. of Philadelphia and Univ. of Pennsylvania Sch. of Med., Philadelphia, and Rainbow Babies Hosp., and Case Western Reserve Sch. of Med., Cleveland. (1333)

28. NALOXONE SIGNIFICANTLY DECREASES PERIODIC BREATHING OF INFANCY. A.R. Spitzer, P. Juliano, K. Peeke, W.W. Fox, Div. of Neonat., Children's Hosp. of Philadelphia, Dept. of Ped., Univ. of Pennsylvania Sch. of Med., Philadelphia. (1519)

29. CONTINUOUS, DIRECT MEASUREMENT OF ICP BY A SUBARACHANOID BOLT IN ASPHYXIATED TERM NEONATES. R.C. Clancy, R.W. Newell, D.A. Bruce, J. Goplerud, W.W. Fox, Dept. of Ped. \& Neurosurg., Children's Hosp. of Philadelphia, and Univ. of Pennsylvania Sch. of Med., Philadelphia. (1363) 
30. TRANSIENT HYPERAMMONEMIA OF THE NEWBORN (THAN) AND UREA CYCLE ENZYME DEFECTS (UCED) DIFFERENTIATED BY CLINICAL PRESENTATION. M.L. Hudak, M.D. Jones, Jr., and S. Brusilow, Johns Hopkins Hosp., Baltimore.

31. PERIVENTRICULAR NECROSIS IN PRETERM INFANTS: SONOGRAPHIC OBSERVATIONS. Raul Bejar, Roanld Coen, T.A. Merritt, Jill Trice, Sami Ikonen, Mary J. Felice, Univ. of California, San Diego, Dept. of Ped. \& Neuro., La Jolla. (1294)

32. ASSOCIATION OF ACQUIRED CYTOMEGALOVIRUS INFECTION AND THE DEVELOPMENT OF BRONCHOPULMONARY DYSPLASIA IN PREMATURE INFANTS. Mark H. Sawyer, David K. Edwards, and Stephen A. Spector (Spon. James D. Connor), Univ. of California, San Diego, Dept. of Ped. and Radiol. (1515)

33. PERSISTENCE OF IMMUNOLOGIC FACTORS FROM HUMAN MILK IN THE INTESTINAL TRACT OF VERY LOW BIRTH WEIGHT INFANTS. R.M. Goldblum, R.J. Schanler, C. Garza, and A.S. Goldman, Dept. of Ped., Univ. of Texas Med. Branch, Galveston and Baylor Coll. of Med., Houston. (1368)

34. NECROTIZING ENTEROCOLITIS (NEC). A RADIOGRAPHIC AND PATHOLOGIC MODEL. David A. Clark, Michael Oliphant, Jeffrey E. Thompson, Lawrence Gordon, John Rokahr, and Karen Lougnot (Spon. by M. Williams), Dept. of Ped., SUNY, Upstate Med. Ctr., and Dept. of Radiol. and Path., Crouse Irving Mem. Hosp., Syracuse. (1315)

35. HEPARIN PREVENTION OF CATHETER RELATED THROMBOSES. M.M. McDoanld, M.L. Johnson, C.M. Rumack, R. Marlar, W.E. Hathaway, Univ. of Colorado Sch. of Med., Dept. of Ped. and Radiol., Denver, Blood Bank of SE Wisconsin, Milwaukee. (1433)

36. CRITICAL SERUM CA FOR CARDIAC FUNCTION: ECHOCARDIOGRAPHIC CORRELATIONS, STUDIES IN IONIZED CA (iCa), EFFECT OF THERAPY IN PROFOUND EARLY NEONATAL HYPOCALCEMIA (HC). P. Venkataraman, R. Sheldon, D. Wilson (Spon. by O.M. Rennert), Univ. of Oklahoma, Dept. of Ped., Oklahoma City. (1543)

37. NECROTIZING ENTEROCOLITIS CAN BE CAUSED BY POLYCYTHEMIA IN THE NEWBORN DOG. M.H. LeBlanc, C. D'Cruz, K. Pate (Spon. by B. Batson), Dept. of Ped. and Path., Univ. of Mississippi Med. Ctr., Jackson. (1418)

38. MEASUREMENT OF MEAN PEAK BLOOD FLOW USING DUPLEX ULTRASOUND IN THE NEONATE. James A. Menke, Paul H. Liu, Mohammed Bashiru, Rex Bickers, Richard McClead (Spon. by Grant Morrow), Dept. of Ped., Ohio State Univ. and Children's Hosp., Columbus. (1435)

39. REDUCTION OF LBW WITH ENHANCED ANTENATAL CARE. Kenneth E. Scott (Spon. by Richard B. Goldbloom), Dalhousie Univ. Fac. of Med., Dept. of Ped., Grace Maternity Hosp., Halifax, Nova Scotia. (1497)

40. PERINATAL ASPHYXIA AND POSTNATAL CHANGES IN SERUM TOTAL AND IONIZED CALCIUM. Nam Dong, Paul Y.K. Wu, Bijan Siassi, Lota Viray, Univ. of So. California Sch. of Med., Lac-USC Med. Ctr., Dept. of Ped., Los Angeles. (1562) 
41. SKELETAL MUSCLE WATER AND ELECTROLYTES AT BIRTH IN THE RABBIT. David M. Coulter, Tim R. LaPine, Dept. of Ped., Univ. of Utah Sch. of Med., Salt Lake City. (1331)

42. VITAMIN E DOES NOT AFFECT NEUTROPHIL FUNCTION IN PREMATURE NEWBORNS. H.J. Meuwissen, M.S. Rhee, R. Carroll, N. Carrasco, H. Risemberg, A. Bartoletti, A. Geis (Spon. by M.L. Cowger), NY State Dept. H1th., Ctr. of Labs and Res., and Albany Med. Coll., Albany. (1437)

43. THE EFFECT OF SLOW LIPID INFUSION AND DOSAGE ON BILIRUBIN BINDING TO ALBUMIN IN THE PREMATURE INFANT. M.L. Spear, G.E. Stah1, M.H. Paul, J.M. Egler, G.R. Pereira, R.A. Polin, Div. of Neonat., Children's Hosp. of Philadelphia, and Dept. of Ped., Univ. of Pennsylvania Sch. of Med., Philadelphia. (1514)

44. ECONOMIC ANALYSIS OF REGIONALIZED NEONATAL CARE FOR LOW BIRTH WEIGHT INFANTS IN THE STATE OF RI. Donna-Jean B. Walker, Betty R. Vohr, William Oh, Brown Univ., Women \& Infants Hosp., Dept. of Ped., Providence. (1451)

45. IN VIVO EFFECT OF FREE FATTY ACIDS (FFA) ON BILIRUBIN (BR) BINDING. Timos Valaes, Kevin Murphy, Richard Wennberg, and Boris Senior, Dept. of Ped., Tufts-New England Med. Ctr., Boston, and Univ. of California, Davis. (1542)

46. LUNG SURFACTANT REPLACEMENT WITH LIPIDS EXTRACTED FROM BOVINE LUNG LAVAGE: EFFECTS OF DOSE AND DISPERSION TECHNIQUE. Edmund A. Egan, Robert H. Notter, Melinda S. Kwong, Doanld L. Shapiro, Dept. of Ped., SUNY at Buffalo, Children's Hosp., Univ. of Rochester Sch. of Med., Strong Mem. Hosp., Buffalo and Rochester. (1447)

47. THE EFFECT OF THEOPHYLLINE ON THE HYPOXIC VENTILATORY RESPONSE IN THE NEWBORN PIGLET: ROLE OF THE VAGUS. Robert A. Darnall (Spon, by John Kattwinke11), Univ. of Virginia Sch. of Med., Dept. of Ped., Charlottesville. (1757)

48. RAT AND HUMAN SURFACTANT ASSOCIATED APOPROTEINS. Jeffrey A. Whitsett, William Hull, Mary A. Petro, and Mark Shapiro, Children's Hosp., Univ. of Cincinnati. (1880)

49. EFFECT OF THEOPHYLLINE ON VENTILATORY RESPONSES OF GROWING PRETERM NEONATES TO COMBINED INSPIRATORY AND EXPIRATORY LOADS. S. Abbasi, E. Sivieri, V.K. Bhutan, M.R. Wolfson, T.H. Shaffer, W.W. Fox, Univ. of Pennsylvania Sch. of Med., Pennsylvania Hosp., Dept. of Ped., Temple Univ. Med. Sch., Dept. of Physiol., Philadelphia. (1854)

50. SHAPE AND MOMENT ANALYSIS OF TIDAL EXPIRATION IN NORMAL (NL) AND BRONCHOPULMONARY DYSPLASIA INFANTS (BPD). Wayne J. Morgan, Robert Tepper, Edith Wilcox, Lynn M. Taussig, and GHMA Pediatricians, Dept. of Ped. and Div. of Resp. Sci., Arizona Hlth. Sci. Ctr., Tucson. (1817

51. ABNORMAL LUNG COLLAGEN RATIOS IN VENTILATED HUMAN NEONATES. Craig Shoemaker, Jerold Last, Karen Reiser, Boyd Goetzman, Dept. of Ped. and California Primate Res. Ctr., Univ. of California, Davis. (1852) 
52. EFFECTIVENESS OF EXTRACTED COW LUNG LIPID (CLL) IN INDUCING AND SUSTAINING NORMAL LUNG FUNCTION IN SURFACTANT DEFICIENT PREMATURE LAMBS. Melinda S. Kwong, Edmund A. Egan, Doanld S. Shapiro, Robert H. Notter, Dept. of Ped. and Physiol., SUNY, Buffalo, Dept. of Ped., Univ. of Rochester. (1794)

53. MEASUREMENT OF EXPIRED ETHANE AND N-PENTANE DOES NOT PREDICT OXYGEN INDUCED DAMAGE TO THE LUNGS OF LAMBS. Thomas Hansen, Harilyn Smith, Alfred Gest and Mark Giesler, Dept. of Ped., Baylor Coll. of Med., Hosuton. (1782)

54. NUTRITIVE VS. NON-NUTRITIVE SUCKING: EFFECTS ON BREATHING PATTERN OF TERM NEONATES. Hortencia G. Luna-Solorzano, Mark L. Clark, M. Dale Peterson and Oommen P. Mathew (Spon. by David K. Rassin), Univ. of Texas Med. Branch, Dept. of Ped. \& Anesth., Galveston. (1808)

55. APNEA CAUSED BY REGURGITATION IN IFNANTS. P. Aravindaksha Menon, Bradley T. Thach, Washington Univ. Sch. Med., Dept. of Ped., St. Louis. (1810)

56. STATIC VS DYNAMIC AIRWAY PRESSURE AND REGIONAL LUNG BLOOD FLOW. B.P. Fuhrman, J.C. Ring, D.L. Smith-Wright, J.E. Lock, R.K. Schutjer and S. Einzig, Ped. Crit. Care, Univ. of Minnesota, Minneapolis. (1774)

57. PULMONARY TOXICITY OF MONOCROTALINE DIFFERS IN NEONATAL, YOUNG AND ADULT RATS. Livia Todd, Michelle Mullen, Peter Olley, Marlene Rabinovitch, Univ. of Toronto, Hosp. for Sick Chidlren, Dept. of Cardiol., Toronto. (1832)

58. TRACHEAL LAVAGE (TLFN) AND PLASMA (PFN) FIBRONECTIN (FN): RELATIONSHIP TO RESPIRATORY DISTRESS SYNDROME (RDS) AND DEVELOPMENT OF BRONCHOPULMONARY DYSPLASIA (BPD). J.S. Gerdes, M. Paul, M.C. Yoder, S.D. Douglas, M.C. Harris, R.A. Polin, Dept. of Ped., Univ. of Pennsylania Sch. of Med., and Children's Hosp. of Philadelphia. (1775)

59. BRONCHIAL HYPERREACTIVITY IN LONG TERM SURVIVORS OF THE NEONATAL RESPIRATORY DISTRESS SYNDROME (RDS). Ian B. Maclusky, Joshua Zarfin, Karen Pape and Henry Levison, Hosp. for Sick Children, Dept. of Pulm. Med., Toronto. (1798)

60. CIRCADIAN VARIATION OF THEOPHYLLINE (T) PHARMACOKINETICS IN ASTHMATIC CHILDREN. P. Scott, M. Smolensky, R. Harrist, W. Kramer, J. Baenziger, B. Klank, H. Eigen (Spon. by R. Schreiner), Dept. of Ped., Path., and Pharm., Indiana Univ. Sch. of Med., Indianapolis, and Sch. of Public Hlth., Univ. of Texas Hlth. Sci. Ctr., Houston. (1848) 